\title{
Н.И. Дыкань
}

\section{НОВЫЕ ДАННЫЕ ОБ ИСКОПАЕМЫХ ОСТРАКОДАХ РАЗРЕЗА «МЫС ПАНАГИЯ॥ (ТАМАНСКИЙ ПОЛУОСТРОВ, СРЕДНИЙ-ВЕРХНИЙ МИОЦЕН)}

\author{
N.I. Dykan
}

\section{NEW DATA ABOUT THE FOSSIL OSTRACODES OF THE PANAGIA SECTION (TAMAN PENINSULAR, MIDDLE-UPPER MIOCENE)}

У караган-верхньосарматських відкладах розрізу «мис Панагія» (Таманський півострів, Росія) знайдено морскі остракоди родів Paradoxostoma, Pontocythere, солонуватоводні остракоди родів Leptocythere, Cyprideis, Loxoconcha, Caspiocypris, Bacunella. Перша міграція представників родів Bacunella, Caspiolla в східні області Паратетіса з Панонського басейну відбулась на початку пізнього сармату.

Ключові слова: середній-верхній міоцен, біостратиграфія, остракоди.

В караганских-верхнесарматских отложениях разреза «мыс Панагия» (Таманский полуостров, Россия) обнаружены морские остракоды родов Paradoxostoma, Pontocythere, солоноватоводные остракоды родов Leptocythere, Cyprideis, Loxoconcha, Caspiocypris, Bacunella. Первая миграция представителей родов Bacunella и Caspiolla в восточные области Паратетиса произошла из Паннонского бассейна в начале позднего сармата.

Ключевые слова: средний-верхний миоцен, биостратиграфия, остракоды.

Karaganian-Upper Sarmatian deposits of the Panagia section (Taman Peninsular, Russia) contain the marine species of genera Paradoxostoma, Pontocythere and brackishwater species of genera Loxoconcha, Cyprideis, Loxoconcha, Caspiocypris, Bacunella. The first immigration of ostracodes Bacunella, Caspiolla genera in the eastern fields of Paratethys from the Panonian basin was at the beginning of Late Sarmatian. Key words: Middle-Upper Miocene, biostratigraphy, Ostracoda.

\section{ВВЕДЕНИЕ}

Опорный разрез средне-верхнемиоценовых (верхнечокракских-нижнемэотических) отложений «мыс Панагия» расположен в югозападной части Таманского полуострова, в 12 км от ст-цы Тамань (рис. 1). В береговом обрыве обнажаются разнофрациальные отложения мощностью 65-70 м, которые детально изучены геологическими (литологическим, палеонтологическим) методами. Биостратиграфическое расчленение отложений ранее было проведено по моллюскам, фораминиферам, наннопланктону, диатомовым водорослям, диноцистам, споро-пыльце [3, 5, 6, 13]. Ископаемые остракоды описаны только в восточном крыле антиклинали между горой Зеленского и балкой Кутря [2]. В.И. Павловской из кровли мэотических отложений были определены виды рода Leptocythere, из одесских слоев нижнего понта - виды рода Caspiolla (C. labiata, C. pontica и др.), из портаферских слоев верхнего понта - виды родов Cyprideis (C.littoralis), Trachyleberis (T. aff. azerbaijdjanica и др.), из босфорских слоев верхнего понта - виды рода Caspiolla (C. liventali, C. venusta и др.), из кровли верхнепонтических отложений в детритовых ракушняках - многочисленные виды рода Cypridacea.

\section{МАТЕРИАЛЫ И МЕТОДЫ}

В северо-западной части разреза на остракоды было отобрано 70 образцов с обязательным опробованием всех литологических маркеров, а также мест предыдущего отбора образцов на палеонтологический анализ по другим группам фауны и флоры. Фотографирование ископаемых створок проведено на сканирующем электронном микроскопе JEOL JSM-6490 LV. При изучении ископаемых остракод проведены тафономический, статистический, зоогеографический, экологический анализы.

\section{РЕЗУЛЬТАТЫ И ИХ ОБСУЖДЕНИЕ}

В разрезе «мыс Панагия» ископаемые остракоды распространены фрагментарно (обнаружены только в караганских, конкских, средне-верхнесарматских, нижнемэотических отложениях), имеют разнообразный 


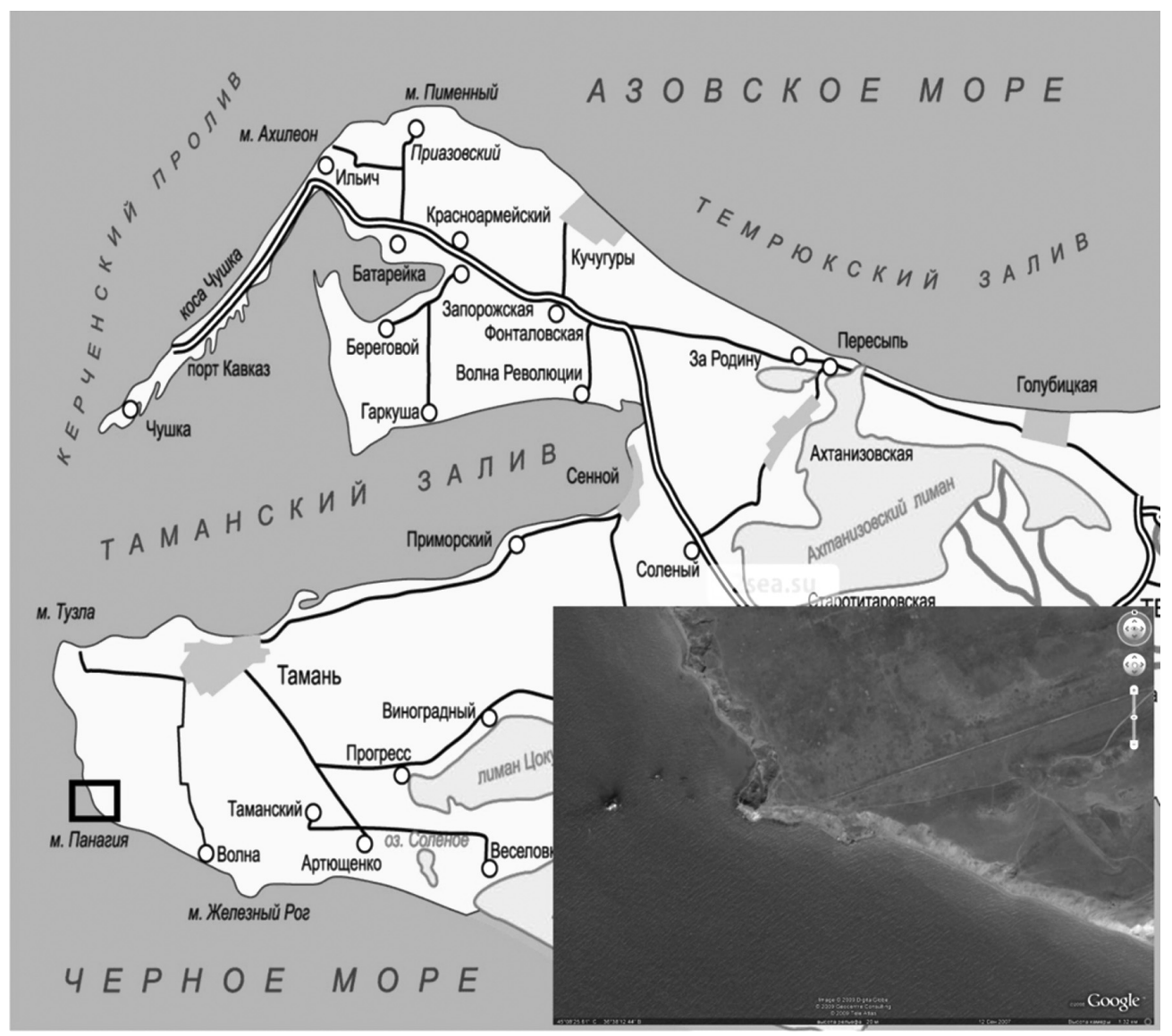

Рис.1. Карта-схема местонахождения разреза «мыс Панагия»

родовой состав (семь родов: Caspiocypris, Bacunella, Leptocythere, Cyprideis, Loxoconcha, Paradoxostoma, Pontocythere), низкое видовое разнообразие (девять видов), малочисленные (все виды представлены единичными створками) (рис. 2).

Первые остракоды (одна створка взрослой особи и одна створка личинки вида Loxoconcha aff. bairdi Mull.) обнаружены в слое 2 (чередование миллиметровых прослоев темно-серых, светло-серых, коричневатых глин) (рис. 3). Вид Loxoconcha aff. bairdi описан только из караганских отложений в восточной части Эвксинского бассейна (западная часть северного склона Кавказа, Гладковская антиклиналь [14]), т.е. является караганским эндемиком, что позволяет датировать по остракодам время формирования отложений слоя 2 караганским временем.

Выше по разрезу, в конкских отложениях (слой 5, глины темно-серые, известковистые, с включениями гипса, раковин моллюсков, отолитов рыб, редких растительных остатков), остракоды представлены единственным морским видом Paradoxostoma sp. (одна раковина взрослой особи), что не противоречит име- ющимся данным о миграции морских представителей подсемейств Paradoxostominae, Cytherideinae, Xestoleberidinae, Aglajocyprinae из Средиземноморского бассейна в Паратетис во время установившейся кратковременной связи в конкское время [9]. В слое 8 (глины темно-серые с зеленоватым оттенком, известковистые, тонкослоистые, с включениями гипса, отолитов рыб, фораминифер; возраст пачки не определен) остракоды представлены единичными особями вида Loxoconcha sp. 1.

Выше по разрезу, в среднесарматских отложениях (слой 13, глины темно-серые, слабоизвестковистые, с включениями гипса, фораминифер, рыбьих остатков и отолитов), видовой состав ракушковых рачков становится более разнообразным. Остракоды представлены четырьмя видами: малочисленными солоноватоводными видами Leptocythere (E.) bosqueti (Liv.) и Cyprideis torosa (Jones), а также единичными особями морских видов Pontocythere sp.1 и Loxoconcha sp.1 (по литературным данным [9], смешанный солоноватоводно-морской состав остракод в Восточном 
Паратетисе сорормировался в конце конки-раннем сармате). Среднесарматский возраст отложений слоя 13 подтверждается присутствием вида Leptocythere (E.) bosqueti, нижней стратиграфической границей которого в Паратетисе (Керченский полуостров, Восточное Предкавказье [9]) является средний сармат, а также присутствием вида Cyprideis torosa, первичный ареал которого сфрормировался в восточных областях Паратетиса в сармате [1, 10, 12, 16] (рис. 3). Об опреснении сарматского бассейна до солености около 8 \% в период накопления слоя 13 свидетельствует появление в среднесарматских отложениях малочисленного солоноватоводного вида Cyprideis torosa [9, 15]. В верхнесарматских отложениях (слои 16-17) морские остракоды исчезли, а видовое разнообразие ракушковых рачков сократилось в два раза. Остракоды представлены только единичными личинками солоноватоводных видов Caspiocypris labiata (Zal.) и Bacunella dorsoarcuata (Zal.). Это первая, наиболее древняя, находка солоноватоводных остракод родов Caspiocypris и Bacunella в восточных областях Паратетиса (по литературным данным $[1,4,8,11,12]$ нижней границей стратиграфического распространения видов Caspiocypris labiata и Bacunella dorsoarcuata считается понт). Выше по разрезу, в слоях 25-26 остракоды представлены только взрослыми особями и личинками солоноватоводного вида Leptocythere (E.) praebaquana (Liv.), который известен в Дакийском бассейне с мэотиса [17], а на Керченском полуострове и в Каспийской области - с понта [8].

\section{ВЫВОДЫ}

В караганских отложениях остракоды представлены индикатором караганского времени в восточных областях Паратетиса Loxoconcha aff. bairdi. В конкских отложениях присутствуют морские остракоды (род Paradoxostoma). Сообщества остракод из среднесарматских отложений имеют смешанный солоноватоводно-морской состав; представлены солоноватоводными остракодами Leptocythere bosqueti, Cyprideis torosa, Loxoconcha sp. и морским видом Pontocythere sp. Сообщества остракод из верхнесарматских отложений представлены только солоноватоводными видами

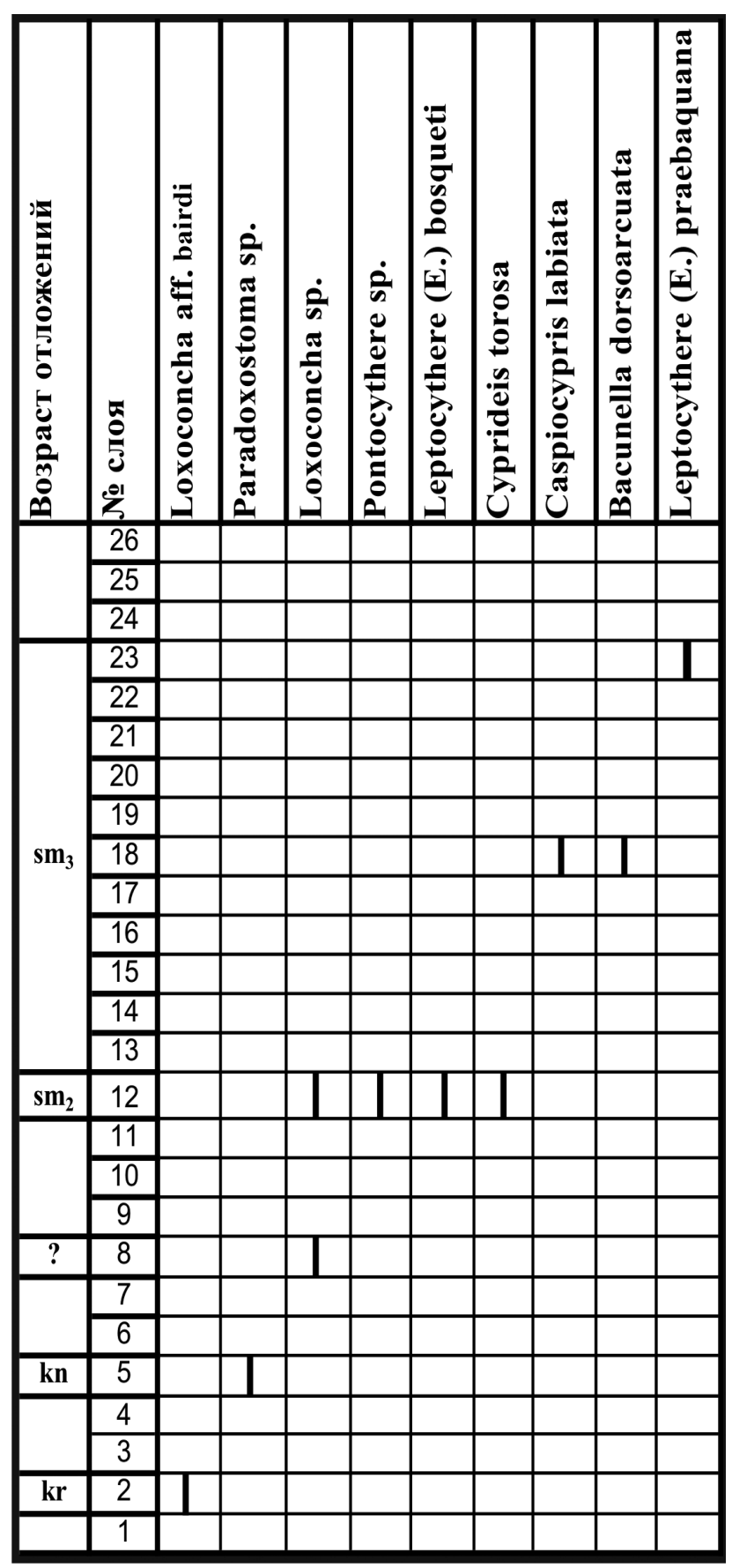

Рис. 2. Распространение и динамика численности остракод в конкских-верхнесарматских отложениях разреза «мыс Панагия»

Caspiocypris labiata, Bacunella dorsoarcuata и Leptocythere praebaquana. Уточнено, что первая миграция представителей остракод из родов Bacunella и Caspiolla из Паннонского бассейна в восточные области Паратетиса произошла в начале позднего сармата, а нижней стратиграфической границей для видов Caspiocypris labiata, Bacunella dorsoarcuata, Leptocythere praebaquana в восточных областях Паратетиса является верхний сармат. 


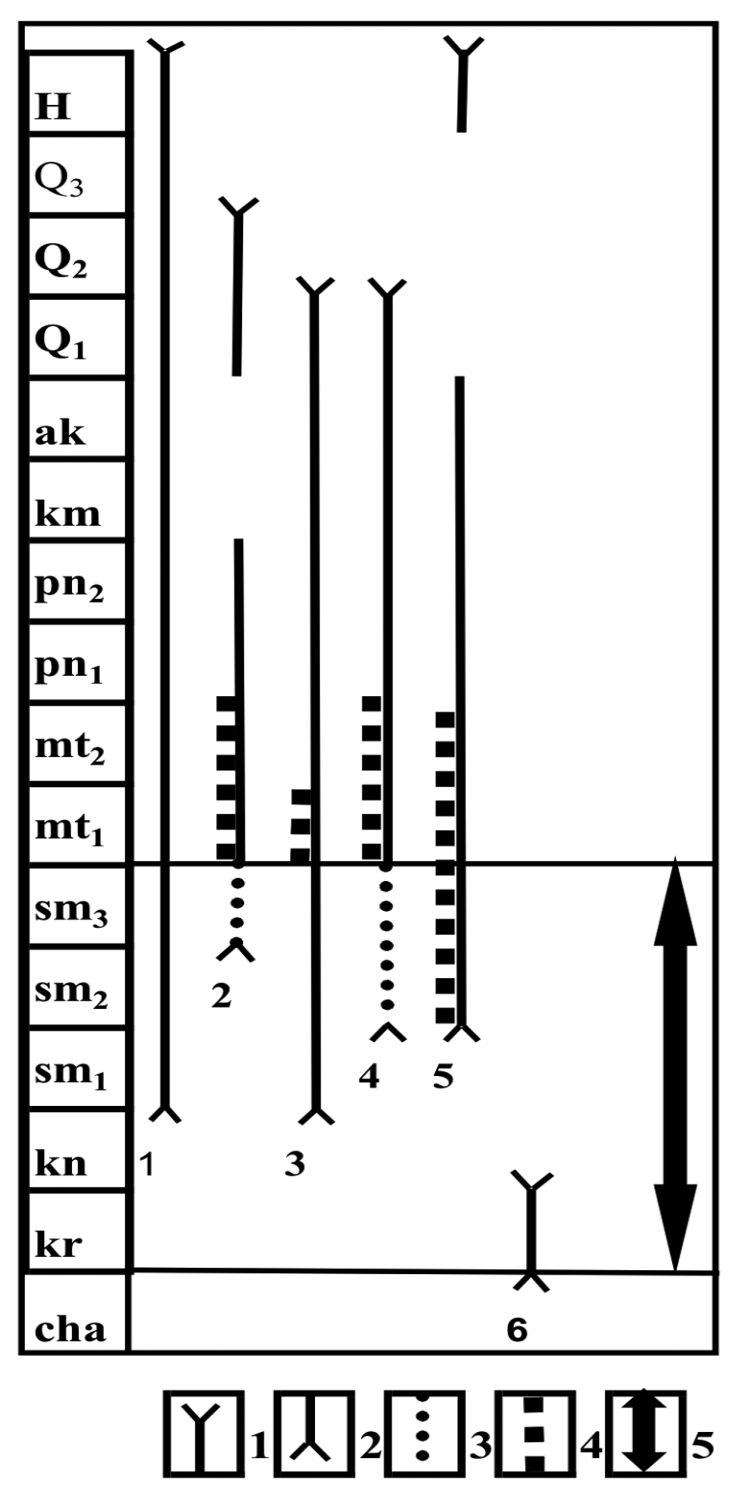

Рис. 3. Стратиграфическое положение остракод разреза «мыс Панагия» по литературным источникам и данным Н.И. Дыкань (цифры на рисунке): 1 - Cyprideis toroca; 2 - Leptocythere praebaquana; 3 L. bosqueti; 4 - Caspiocypris labiata; 5 - Bacunella dorsoarcuata; 6-Loxoconcha aff. bairdi.

Условные обозначения: 1 - верхний предел распространения таксона; 2 - нижний предел распространения таксона; 3 - стратиграфический интервал вида, впервые установленный для Паратетиса; 4 - дополненные автором данные о стратиграфическом распространении таксона в восточных областях Паратетиса; 5 - геологический возраст отложений

1. Агаларова Д.А., Кадырова З.К., Кулиева С.А. Остракоды плиоценовых и постплиоценовых отложений Азербайджана. - Баку: Азгостехиздат, 1961. $-420 \mathrm{c}$.

2. Ананова Е.И., Волкова Н.С., Зубаков А.А. и др. Новые данные по Таманскому опорному разрезу мио-плиоцена Причерноморья // Докл. АН СССР. 1985. - Т. 284, № 4. - С. 925-928.
3. Андрусов H. Геологические исследования на Таманском полуострове. - Москва, 1899. - 377 с.

4. Векуа М.Л. Остракоды киммерийских и куяльницких отложений Абхазии и их стратиграфическое значение. - Тбилиси: Мецниереба, 1975. - 137 с.

5. Головина Л.А., Гончарова И.А., Ростовцева Ю.В. Новые данные по биостратиграфии (наннопланктон, моллюски) и литологии среднего миоцена Таманского полуострова и Западного Предкавказья // Стратиграфия. Геол.корреляция. - 2004. - Т . 12, № $6 .-$ C. 103-112.

6. Застрожнов А.С., Попов С.В. Опорные разрезы неогена Восточного Паратетиса (Таманский полуостров). Путеводитель экскурсии. - Волгоград; Тамань, 1998. - 76 с.

7. Зубаков В.А. Глобальные климатические события неогена. - Л.: Гидрометеоиздат, 1990. - 220 с.

8. Кармишина Г.И. Остракоды плиоцена юга европейской части СССР. - Саратов: Изд-во Сарат. ун-та, 1975. - 376 c.

9. Кармишина Г.И., Шнейдер Г.Ф. Членистоногие. Ракообразные. Остракоды // Стратиграфия СССР. Неогеновая система. - М.: Недра, 1986. - Т. 2. - С. 289-295.

10. Кашеварова Н.П., Мандельштам М.И. Надсемейство Суtheracea // Основы палеонтологии. Членистоногие, трилобитообразные и ракообразные. - М.: Госгеолтехиздат, 1960. - С. 365-411.

11. Коваленко А.Л. Кандониды (Candonidae, Ostracoda) юго-запада СССР. - Кишинев: Штиинца, 1988. - 175 с.

12. Мандельштам М.И., Маркова Л.П., Розыева Т.Р., Степанайтыс H.E. Остракоды плиоценовых и постплиоценовых отложений Туркменистана. Ашхабад: Изд-во АН Туркмен. ССР, 1962. - 289 с.

13. Филиппова Н.Ю., Головина Л.А., Пинчук Т.Н., Радионова Э.П. Микропалеонтологическая характеристика миоценовых отложений опорного разреза северо-восточного Причерноморья «гора Зеленского - мыс Панагия» // Микропалеонтология в России на рубеже веков. - М.: ГЕОС, 2005. C.151-153.

14. Шнейдер Г.Ф. Миоценовая фауна Крыма и Кавказа // Микрофрауна нефтяных месторождений СССР. Л.; М.: Гостоптехиздат, 1949. - С. 89-179.

15. Шорников Е.И. Подкласс остракоды или ракушковые раки. Ostracoda Latreille // Определитель фауны Черного и Азовского морей. - Киев: Наук. думка, 1969. - T. 2. - C. 163-260.

16. Fordinal K., Zlinska A. Fauna vrchej casti holicskeho suvrstvia (sarmat) v Scalici (viedenskapanva) // Mineralia Slovaca. - 1998. - № 30. - S. 137-146.

17. Olteanu $R$. La faune d'ostracodes ponties du Bassin Dacique // Chronostratigraphie und Neostyratotypen. Neogen der Westlichen («Zentrale») Paratetis. Pontien. - Zagreb; Beograd, 1989. - Bd. 8. - P. 722-751.

Институт геологических наук НАН Украины, Киев E-mail: natadykan@mail.ru 